\title{
Shakespeare \& Tradução: Uma conversa com Lawrence Flores Pereira ${ }^{1}$
}

Davi Pinho* e Leonardo Bérenger Alves Carneiro**

No dia 12 de agosto de 2020, às 17h, o projeto Literatura Inglesa Brasil, comandado no Instagram (@literaturainglesabr) pela curadora e idealizadora do projeto, Marcela Santos Brigida, e que tem um braço institutional na extensão da Universidade do Estado do Rio de Janeiro (UERJ), sob a coordenação do professor Davi Pinho, realizou uma conversa sobre "SHAKESPEARE \& TRADUÇÃO" com Lawrence Flores Pereira, professor da Universidade Federal de Santa Maria (UFSM). A ideia inicial era fazer uma live de lançamento de sua recém-publicada tradução de Rei Lear pela Penguin/Companhia das Letras. Como o Literatura Inglesa Brasil intentava promover uma verdadeira conversa em torno da tradução shakespeariana de forma geral, e da nova tradução do Lawrence em especial, Davi e Marcela solicitaram perguntas a colegas com trabalho de referência na área e convidaram o shakespeariano Leonardo Bérenger, parceiro do projeto na PUC-Rio, para mediar a conversa com Lawrence ao lado do Davi. As/os convidadas/os toparam e a conversa aconteceu no Instagram! A entrevista a seguir é resultado desse trabalho coletivo, que contou com as perguntas das professoras Fernanda Medeiros, Maria Alice Antunes e Maria Aparecida Salgueiro, do Departamento de Letras Anglo-germânicas da UERJ; da professora Marcia A. P. Martins, do Departamento de Letras da PUC-Rio; e de Marlene Soares dos Santos, shakespeariana emérita da Faculdade de Letras da UFRJ.

\footnotetext{
${ }^{1}$ Universidade Federal de Santa Maria.

* Universidade do Estado do Rio de Janeiro.

** Pontifícia Universidade Católica do Rio de Janeiro.
} 


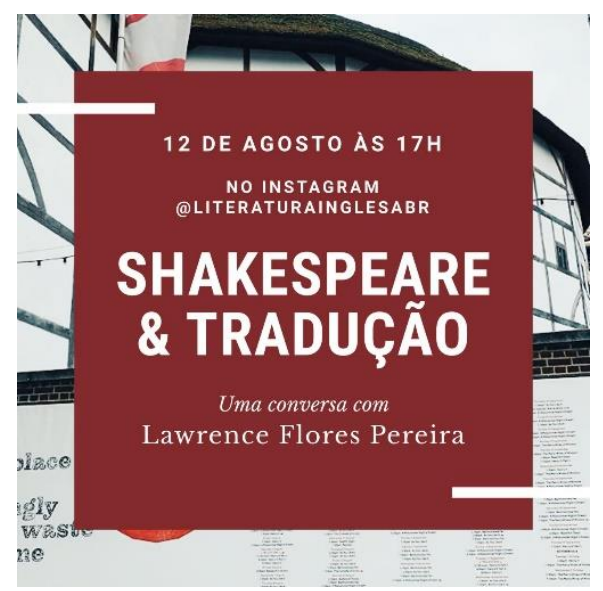

Davi Pinho: É um enorme prazer receber você neste evento uerjiano, Lawrence, e é um prazer ainda maior vê-lo aqui neste canal do Instagram, que é capitaneado pela Marcela Santos Brigida, doutoranda em Literaturas de Língua Inglesa, minha orientanda na UERJ, e que faz este trabalho incrível de divulgação e de discussão informada nas redes. Para esta live-conversa, nós contamos com perguntas de três colegas do departamento de Letras Anglo-germânicas do Instituto de Letras da UERJ: Fernanda Medeiros, nossa shakespeariana da casa, Cida Salgueiro, que é pioneira em nosso departamento por ter criado o Escritório Modelo de Tradução Ana Cristina César, e Maria Alice Antunes, referência nos estudos de história da tradução e de retraduções. Entrando no grupo, nós temos da PUC-Rio não só Leonardo Bérenger, que media comigo esta conversa, mas Marcia A. P. Martins, referência nos estudos sobre traduções e adaptações shakespearianas, além de Marlene Soares dos Santos, da UFRJ, shakespeariana decana no Rio de Janeiro.

Para começar, Lawrence, eu gostaria que você falasse um pouco dessa sua trajetória até ter chegado a esse projeto tradutório das tragédias shakespearianas, que já lhe rendeu um Prêmio Jabuti, é bom lembrar, pela tradução de Hamlet. Eu acho que não é exagero dizer que suas traduções são marcadas por verdadeiros estudos ou por constantes reflexões. Então, fale um pouco para a gente dessa sua trajetória de poeta, tradutor, professor, que 
desponta com tanta força, com tanta vitalidade, tanta erudição, neste novíssimo Lear.

Lawrence Flores: Davi, muito obrigado pela palavra, estou muito feliz de estar aqui também, com Cida, com Marlene, com o grupo inteiro da UERJ, com Marcia. Para mim é um prazer estar aqui para falar um pouco dessa trajetória.

A minha trajetória se iniciou, mais propriamente, com a minha relação com a poesia: a tradução tem sido, já por muito tempo, no Brasil e no mundo, uma das várias atividades de alguém que muito cedo desperta para a poesia. A relação entre a atividade de traduzir e de poetar são diferentes, mas o poeta busca na tradução antes de tudo um exercício, uma espécie de rito de passagem para a poesia propriamente dita - e se lança não numa superação da chamada angústia de influência, mas muito mais numa assimilação dos autores admirados. Finalmente, tenho a gana de ver alguns autores, aqueles que acho genuinamente traduzíveis, em minha língua. Sou, além de tradutor, também um leitor de traduções, acredito que há uma diferença substancial entre ler algo em sua língua materna e em outra língua, e sei que a cada nova tradução ocorre, no sistema cultural de um país, um pequeno, mas importante abalo. No entanto, minha experiência com a tradução de teatro e drama tem uma história que conjuga diversos elementos: meu interesse pela tragédia antiga, da primeira modernidade e da Age Classique francesa, por um lado, e, por outro, pelas técnicas poéticas orais pelas quais passei a me interessar pelas mais diversas vias: de um lado, na minha curiosidade pela literatura pré-literária, ou seja, aquela poética que se originava, de um modo ou de outro, em práticas orais, técnicas, musicais como o do verso homérico ou até mesmo do trímetro iâmbico da tragédia antiga. Curiosamente, meu mestrado foi muito inspirado pela injunção de que os sistemas "formulaicos" da poesia poderiam ser encontrados e entendidos com mais facilidade - para nós - na nossa própria tradição oral do repente nordestino, a despeito das radicais diferenças dessa tradição com aquela que encontramos, digamos, em Homero ou no estilo homérico que interessou a Milman Parry, estudioso da poesia tradicional servo-croata. De 
fato, na tradição poética do Nordeste uma comunidade gigantesca possivelmente o maior corpus literário da língua portuguesa - de poetas, cantadores, repentistas e cordelistas mantiveram uma tradição de elaboração oral do verso. Minha preocupação, na época, era de encontrar uma linguagem que possuísse certas qualidades da oralidade. Mas qual das qualidades da oralidade? Uma delas é a de ser imediatamente decodificável pelo seu público: a poesia popular nordestina do repente existiu sempre como algo comunitário, algo a ser feito na praça ou na fazenda. Então, esse foi um dos caminhos. Um outro caminho, obviamente, é o de conhecer essa oralidade nas culturas que chamamos de culturas influenciadas pelo legado clássico, que necessariamente manipula um material em que se sedimenta uma história toda de intervenções e contribuições como a retórica, como a cultura inglesa, de língua inglesa, cultura de língua francesa e assim por diante.

Comecei a me perguntar sobre os resquícios da oralidade até mesmo no alexandrino francês, que não raro é associado a Racine e a sua sofisticação particular e ao chamado neoclassicismo francês, mas que tem, por outro lado, uma rica sedimentação remontando ao medievo e que, ao contrário do que pode se pensar, continua no século XVIII no contexto das práticas teatrais do teatro do Grand Siècle. Minha trajetória como tradutor de Shakespeare passa justamente por uma questão básica: como é possível resgatar a oralidade e a clareza do teatro elisabetano e jacobino, o qual, curiosamente, combina a prosa com a poesia e, mesmo dentro das formas metrificadas dominadas pelo princípio iâmbico, adota formas que são muito mais conversacionais e, nesse sentido, bastante diferentes daquelas que Shakespeare utilizou, digamos, em seus sonetos. Acreditava, desde o início, nas minhas leituras de modo geral, das traduções de Shakespeare, não só em língua portuguesa, que era possível tentar de novo - depois das importantes contribuições em tradução em prosa de Millôr Fernandes - e buscar uma coloquialidade teatral similar que se fizesse, no entanto, de modo versificado (naquelas partes em verso). Por volta de 1995, quando iniciei esse projeto, o cenário da tradução apontava cada vez mais para as traduções em prosa de Shakespeare. Era preciso redobrar a aposta da poesia e da métrica - mas sob 
outros princípios, não mais pelo uso do decassílabo que fora utilizado nas traduções de tantos precursores como Manuel Bandeira, Carlos Alberto Nunes e Barbara Heliodora, e tantos outros.

Já na França, durante o período de doutoramento, comecei a fazer as primeiras experimentações. Porque adotei a forma de um dodecassílabo somente parcialmente calcado no sistema rítmico do Alexandrino francês, o verso usado na tradução ao mesmo tempo acompanha e viola as regulações "canônicas" desse antigo verso. Por outro lado, como, na literatura brasileira, a idade de ouro do alexandrino se deu no período do decadentismo, parnasianismo e simbolismo - pelo impacto formidável da poesia francesa do novecentos sobre nossos poetas - não faltou quem me perguntasse se minha predileção por esse verso vinha de uma espécie de filiação minha a essas escolas. Na verdade, a despeito de alguma francofilia literária, minha resposta era que, longe de querer relançar aquele espírito, eu partia de uma observação simples e relativamente lógica: a de que o decassílabo, usado na tradução por diversos tradutores antes de mim, em geral não comporta o volume lexical e/ou semântico que Shakespeare conseguia colocar em cada um de seus versos. A razão disso é conhecida e já foi discutida: o inglês possui mais palavras monossilábicas e dissilábicas, e portanto, comparativamente, é capaz de dizer mais (volume semântico e lexical maior) ao longo de determinada extensão métrica. Há duas consequências do uso do decassílabo na tradução do pentâmetro iâmbico de língua inglesa:

a) se o tradutor, como Barbara Heliodora, decide traduzir um verso do original por um verso na língua-alvo, ele necessariamente precisará lançar mão de procedimentos compressivos, através de atos supressivos ou reestilizatórios, como o corte de palavras, artigos ou a simplificação de frases. Isso é certamente possível, mas resta a questão de se é sustentável ao longo de uma peça inteira, sem que se perca uma carga semântica e lexical considerável;

b) se o tradutor decidir não seguir o paralelismo verso-a-verso - e aqui temos o caso de Aíla de Oliveira Gomes, em particular em sua tradução de Rei Lear - ele será obrigado espraiar (espraiamento interverso) o material semântico-lexical para os versos seguintes e reconstruir a convergência entre 
forma e conteúdo sob um princípio diferente do que o verso original. Um parêntese aqui: é preciso dizer que nem mesmo uma tradução com dodecassílabos consegue sempre evitar qualquer um desses procedimentos - a reestilização é inevitável em qualquer tradução de teatro -, mas, comparativamente, o uso do dodecassílabo permite que a unidade versoconteúdo se mantenha com uma eficácia e constância muito mais considerável. Permite, além disso, uma "replicação" interessante da sintaxe do original - uma proximidade da estranheza da frase não raro tortuosa de Shakespeare. Garante também uma inclusão maior do léxico do português, em particular daquelas palavras que, por serem longas demais silabicamente, eram as primeiras a ser trocadas por uma sinonímia mais curta. Sem dúvida, a ideia de concisão métrica deve sempre estar no horizonte de um tradutor. Alongar demasiadamente um verso em comparação com o seu original pode ter por consequência a perda daquelas qualidades "compressivas" do verso. Mas o dodecassílabo permite que os efeitos poéticos originados de um verso ricamente ritmado apareçam formidavelmente.

Todo esse projeto nos seus momentos iniciais, incertos, só foi possível com o incentivo da Kathrin Rosenfield durante todos esses anos - que assina também a introdução do Rei Lear comigo. Ela é a mente que idealizou, entre 2002 e 2003, as encenações de Antígona e de Hamlet. Em 2005 o Hamlet, o mesmo da tradução atual da coleção Penguin, foi encenado em Porto Alegre no teatro São Pedro e mais tarde no Solis de Montevidéu. E encenamos também Antígona, que eu traduzi antes do Hamlet, já treinando esse verso.

Davi Pinho: Kathrin e você fizeram um trabalho incrível na introdução, que volta às fontes de Shakespeare e expõe uma pesquisa rica em informação e erudição, mas sem abdicar de produzir suas próprias chaves de leitura.

Leonardo Bérenger: Um aspecto que você ressaltou a partir da pergunta do professor Davi foi o privilégio da oralidade. E é justamente nesse sentido que a pergunta da professora Maria Aparecida Salgueiro, da UERJ, aponta. Eu vou trazer a pergunta da Cida e vou tentando puxar para a experiência da 
tradução shakespeariana. Eu vou fazer um pequeno adendo à pergunta da Cida: "Gostaríamos de ouvi-lo, entre tantas escolhas de possibilidades de diálogo, sobre uma das características do trabalho de tradutor marcantes em sua obra, a saber, a oralidade no equilíbrio de clareza e poesia, já título de artigo, objeto de debates, foco de análise da tradução como experiência de acréscimo de vozes textuais na produção de novo texto, à medida em que camadas de leitura vão sendo acrescentadas. Enviamos nossas congratulações a você - um dos maiores tradutores do Brasil contemporâneo - por assumir os consideráveis desafios da complexidade da atividade tradutória, nesta que é tantas vezes vista como uma missão quase impossível". Eu faço um adendo à pergunta da professora Maria Aparecida: seria essa intenção, esse privilégio da comunicação, essa busca pelo equilíbrio entre aspectos de poética e um texto que comunica, o que motiva a sua opção por um verso em doze sílabas?

Lawrence Flores: Oralidade, clareza e poesia metrificada são coisas que, no senso comum, nem sempre vão juntas. Nós temos, por exemplo, em língua portuguesa, uma longa tradição de uma bela obscuridade, que admiro e da qual absorvi alguns aspectos, pois escrever poesia é também mensurar clareza e obscuridade. Valéry teria feito, em uma de suas cartas, o comentário de que seria necessário aclarar suas ideias escrevendo obscuramente. Nós temos uma tradição de obscuridade em nossa cultura poética, e talvez a exceção mais notável seja a poesia popular. Poderíamos falar de camadas sobrepostas de obscuridade: renascimento, barroco, linguagem poética simbólica do simbolismo - e assim por diante. A oralidade, de algum modo, está relacionada com a clareza, a imediatez, a capacidade de um conjunto de versos ser "entendido" no instante em que está sendo pronunciado. Há um segundo aspecto sobre esse problema: como desde muito cedo os tradutores elegeram o decassílabo para traduzir o verso dramático de Shakespeare, eles foram muitíssimas vezes obrigados, como já mencionamos, a praticar a compressão e supressão do material lexical e semântico do original - o que os afastou não raro de certo traço oral próprio da poética dramática de Shakespeare. A suposição de que o decassílabo, só porque tinha dez sílabas como o pentâmetro iâmbico, daria conta do volume do original leva quase 
que automaticamente, no caso (a) mencionado acima, a procedimentos de supressão em que ocorre também um afastamento das qualidades da oralidade. Estamos aqui falando de oralidade poética e não de oralidade em geral: da poesia declamada, falada para ser entendida por um público, e isso inclui desde o contexto de uma "cantoria" ou repente nordestino até o contexto teatral no qual o uso do verso sem dúvida se adequa à audição, mesmo nos seus momentos mais "poéticos" e até empolados.

Assim, retornando à pergunta da Cida - "como equilibrar a poesia e a oralidade em privilégio de um texto que comunica" - acredito que esse equilíbrio é feito quando o tradutor faz boas escolhas desde o início e que podem ser auferidas pela análise do material a ser traduzido. Por exemplo, traduzir Shakespeare pressupõe diversas exigências. $O$ primeiro é a equivalência semântico-estético-lexical e sintática; o segundo é a comunicabilidade teatral; o terceiro é a ritmicidade que, em Shakespeare, oscila entre ritmos anódinos, não raro imitados do coloquial, e ritmos "marcados" iterativos ou "hiperpoéticos", em que se observa claramente a insistência iterativa dos versos. No trabalho com atores, há duas possibilidades de "dizer" os versos da minha tradução de Shakespeare. De um lado, um modo "estudado", caracterizado pela concentração do poeta na tonalidade específica de uma voz e que determina muitas vezes até mesmo o "caráter" do personagem ou o registro no qual ele está falando (meditativo, casual, etc); e por outro lado um modo "em galope", como uso no jargão dos ensaios, em que o ator deve evitar colorir excessivamente com sua voz, com tons específicos, o conjunto que está sendo lido. No caso dos ritmos anódinos, o treinamento do ator pode incluir certo aporte interpretativo do próprio ator sobre como algo deve ser dito; no caso dos ritmos binários ou ternários (iambos e anapestos) contínuos, estamos muito mais próximos da recitação fria de longas passagens, evitando, contudo, em boa parte dos casos, a recitação bombástica que pode se tornar risível. A combinação dessas duas formas é talvez uma das características mais notáveis do pentâmetro iâmbico de Shakespeare, que nem segue de modo absoluto a formalidade do verso nem tampouco renuncia a suas vantagens rítmicoacentuais. Agora, se pensarmos isso na língua de nossas formas poéticas, a 
conclusão a que se chega é que devemos usar o verso, evitando, contudo, ou evitando pelo menos em parte, em certos momentos, aquelas dentre suas formas repetitivas (como acentuação obrigatória) que tendem a ofuscar um dos aspectos mencionados acima. Deve-se encontrar um verso com suficiente repetitividade rítmica (como o pentâmetro iâmbico), mas também com possibilidades transgressivas que nos permitam sair do poético ao coloquial: quero acreditar que o verso que nos permite isso em português, com mais eficácia, é o dodecassílabo, desde que trabalhado com inúmeras variações, desde que afastado de sua matriz francesa - sem destruí-la de todo.

É muito importante também falar que, ao traduzir Shakespeare, devemos manter essa "oxigenação" interna do verso que permite uma expressividade e a tonalidade. A tonalidade é aquilo que permite o nuançamento e evita o estilo excessivamente solene ou hierático que muitas vezes resulta do manejo clássico da tradução. Assim, é muito diferente dizer "não é bem isso que estou dizendo" (com ênfase na pronúncia do bem) e "não é isso que estou dizendo", como no caso seguinte, quando Regan admoesta Lear:

Esses deslumbres, senhor, têm bem o sabor

De outras de vossas mais novas chacotas.

O "bem" aqui não é apenas um intensificador, mas uma tonalidade irônica sutil. Basta pensar a frase sem esse advérbio minúsculo para entender o quanto a afirmação de Goneril fica pobre e inexpressiva. A tonalidade é muito ajudada por partículas como esta, por artigos, preposições e muitas outras partículas ou palavras que lhe dão cor. Ouvimos a voz de Goneril, sentimos até mesmo a sua mordacidade - tanta coisa suscitada por uma minúscula partícula. Essa tonalidade só conseguimos trazê-la à tona se tivermos o espaço para isso. A regra para a escolha do verso é: nem muito largo que incentive a preguiça, nem muito estreito que esmague a expressão e a tonalidade. Essas partículas, desnecessário dizer, são, no teatro, fundamentais. Os atores as descobrem no ato do ensaio - e fazem maravilhas com elas. 
Davi Pinho: Eu lembro que o Oscar Bastian Pinto também traduziu em dodecassílabo, e você faz um uso muito particular dessa tradição nas traduções shakespearianas. Nesse gancho, eu aproveito e trago as vozes da Alice Antunes, da UERJ, e da Marcia Martins, da PUC-Rio, que fazem perguntas contíguas, justamente sobre seu impulso de retradução. Você já deu algumas pistas nessa sua última resposta. A Alice cita o projeto coordenado pela Marcia na PUC-Rio, a base de dados "Escolha seu Shakespeare", e diz que "até poucos anos atrás existiam 11 traduções publicadas de Rei Lear, outras dez de Otelo e 14 de Hamlet". A pergunta que Alice faz é: "o que faz um tradutor tornar a traduzir uma obra já traduzida? $\mathrm{O}$ que faz um tradutor tornar-se um retradutor?" E, complementando a Alice, a Marcia nos lembra que as retraduções "podem refletir mudanças nas normas, nos valores e poéticas da cultura tradutora, como também provocar mudanças ou esperar novas formas de ler e apreciar o texto de origem". A pergunta da Marcia é: “Qual tem sido a sua principal motivação e outras também, se houver, para retraduzir as tragédias mais emblemáticas (e também as mais traduzidas) do cânone shakespeariano?"

Lawrence Flores: Respondendo antes à pergunta da Alice, creio que o impulso de um tradutor para a retradução pode ser muito diverso, e se poderia aqui aventar inúmeras razões para essa prática. No meu caso, o impulso se origina da constatação de que é possível dar maior expressividade para Shakespeare no português, sem transgredir sua poética de contrastes que distingue poesia e prosa; da vontade de oferecer ao ator e ao diretor um texto poético representável e de dicção que cabe na embocadura do ator; de oferecer ao público também um texto em que se percebe a integridade lexical, expressiva, semântica e rítmica do original e que esteja informado pelos estudos shakespearianos que evoluíram no último século. Portanto, é a vontade de criar um texto que satisfaça ao mesmo tempo - numa espécie de reintegração - nosso desejo de transcrição original e de expressividade estética. Por outro lado, Shakespeare, curiosamente, não foi um autor muito impactado pela teorização e prática tradutória brasileira que se inicia com o concretismo. Esta afetou muito mais 
a tradução de poesia lírica (e outras) e menos a poesia dramática. Quando retomei a tradução em versos de Shakespeare por volta de 1998, ainda estávamos num ambiente tradutório intocado pelas práticas dessa escola tradutória. Em outras palavras, o impacto da escola "concretista" (chamemos assim) de tradução não atingiu a obra de Shakespeare, e mesmo as tentativas de Augusto de Campos e de Décio Pignatari na tradução do drama são insuficientes porque de algum modo, justamente, não foram pensadas também para o teatro, mas muito mais como peças poéticas. É necessário "colonizar" melhor esse lugar mal explorado que está entre a poesia (lírica, marcadamente formal) e a prosa - que é o lugar estranho do verso de Shakespeare no drama e que somente agora vai ser praticado no Brasil na sua inteireza.

Com respeito à minha escolha de traduzir as tragédias mais emblemáticas acho que a melhor resposta é meu interesse pela tragédia. E também porque, como tinha um projeto que eu acreditava renovador, encontraria mais impacto pela tradução daquelas peças que já haviam sido traduzidas, para que assim o próprio público pudesse avaliar, linha a linha, a grande diferença na expressão final. Sabia que poderia atingir uma coloratura nova para as tragédias e sabia também que, ao traduzi-las, estaria pondo esse experimento ao lado dos esforços de outros tradutores, como Barbara Heliodora e Millôr Fernandes. Estava também propondo não uma tradução extensiva mas intensiva, mais microscópica, mais detalhista naquele domínio em que os tradutores haviam tentado o máximo de seu talento. São também peças mais conhecidas e, assim, um maior público entraria em contato com essa inovação. Outra razão para uma nova tradução está no fato de que pertenço já a uma geração com imenso acesso a livros e documentos, comentários, tal como era impossível para as gerações precedentes: isso afeta consideralmente as soluções, em particular aquelas que dependem do contexto cultural da época que se inscreve nas peças de Shakespeare não raro de modo microscópico - com verbos originários de escritos alquímicos, por exemplo, ou ainda da ciência médica do período: hoje temos acesso a um volume de material que nos faz ver melhor a estranheza impressionante dos texto de Shakespeare. Trazer isso ao português sem soar artificial - mas 
apenas com o artifício retórico-teatral - é o grande desafio. Retraduzimos porque passamos a ouvir outras coisas ou somos capazes de refazê-las de outro modo. E finalmente porque viemos depois desse grande período de traduções iniciado pelos concretistas no Brasil - usando de uma combinação de erudição, precisão e liberdade.

Leonardo Bérenger: Lawrence, eu acho que fica muito evidenciado, sobretudo a partir dessa sua fala, como você está o tempo todo levando vários aspectos em consideração quando você se senta para traduzir Shakespeare: a comunicabilidade, os aspectos formais, a sua dívida, se você me permite dizer, com os tradutores que lhe antecederam. A crítica shakespeariana é uma das maiores massas críticas do mundo, e eu lhe pergunto se você não acha que a crítica afeta esse trabalho de retraduções. Estar em contato com a crítica dá a você vontade de traduzir? Críticos chamam seu olhar a diferentes aspectos das peças? Quando pensamos em um autor como Shakespeare, o tradutor é afetado pela crítica?

Lawrence Flores: Essa é uma das questões mais importantes quando traduzimos depois dessa verdadeira avalanche crítica que inclui não apenas crítica, mas estudos de contexto, atravessamentos psicanalíticos, históricos, textuais, feministas e tantos outros. Gostaria aqui de dar um exemplo onde a "atenção" crítica nos informa a nós, tradutores, e depois quero falar um pouco de como ela pode também fazer o tradutor pesar a mão na tradução de algo que poderia ser traduzido com mais simplicidade. É pela via da psicanálise e dos estudos feministas, por exemplo, que Janet Adelman escreveu seu livro seminal Suffocating Mothers, que põe o holofote sobre questões que somente poderiam surgir com mais força em uma época pósfreudiana. Nas peças de Shakespeare, as relações de parentesco, a impressionante misoginia manifestada por personagens como Hamlet, Otelo e mesmo Lear, o jogo de inversões de gênero e tantos outros aspectos não apenas nos fizeram ver algo que estava invisível até então. Para o tradutor, essas iterações repetitivas de temas como o do parentesco (incestuoso) podem - no instante em que se revelam não apenas na sua ocorrência específica mas como manifestação de um arcabouço complexo de sensações, 
conceitos e pré-conceitos - escancarar o campo da sinonímia, tão importante para o tradutor, pois, ao ter seu arcabouço revelado, o tradutor também acessa todas as suas fórmulas potenciais na língua de Shakespeare. Ou seja, a sinonímia permite assim que a "equivalência" com o original não se restrinja à palavra (léxico), à literalidade, mas ao uso de outras expressões similares que não se encontram nos nossos dicionários analógicos - há todo um campo em torno do ideologema que o tradutor pode utilizar. Por um outro lado, há cuidados a se tomar. A teoria e os estudos de contexto esclarecem às vezes as noções de modo a colocá-las em destaque, deixando outras noções em silêncio, e há o perigo do tradutor transformar em fetiche certas noções. Eu vejo muitas traduções que são afetadas até demais por certos conceitos que foram destacados pela antropologia e outros estudos. É o caso, no helenismo, quando um conceito muito característico como "tychê" (sorte, fortuna) é investido de uma particularidade tal, de uma especificidade "grega" tal, que o tradutor se recusa a traduzi-la, resultando numa simples transcrição do termo em grego. Ocorre aí um desequilíbrio que se origina da distorção que todo o estudo crítico produz, de enfatizar um aspecto. $\mathrm{O}$ tradutor esquece que, além desses termos, há tantos outros que por acaso não foram enfatizados pelos estudos - e o resultado é algo desigual.

Mas, enfim, de modo geral, a crítica e os estudos nos dão awareness, atenção, para detalhes que, muitas vezes, não percebemos com a devida atenção. Se as teses que aparecem na crítica são aceitas, isso quer dizer que elas se tornam uma ressonância de fundo na mente do tradutor. A mesma coisa acontece, Leonardo, com relação às variações dos diversos textos de Shakespeare que tornam a tarefa de tradução uma viagem rica na história editorial e poética desses textos. Como lidar com as variações? Fundi-las? Aceitar edições "conflated"? Se fazemos a conflação, como unir a variações? Em minha tradução de Rei Lear, eu uso as variações do in-quarto e o in-folio, as duas principais edições do Lear. Mas eu não usei as duas, porque eu queria fazer um texto único, ou o fólio ou o quarto, eu decidi fazer uma fundida, mas tendo ao fundo a ressonância, as alternativas de ambas, no sentido que eu queria entender qual é o processo da variação, como ela se dá - e assim 
produzir a minha própria edição. Eu queria entender como é que ocorre a variação, que tipo de palavra é trocada por qual. Porque ao entender isso, eu como tradutor também me dou esse direito de trocar dentro de um controle imaginário preciso - e estamos aqui novamente tratando de abertura do campo de sinonímias. Porque eu quero uma licença, mas uma licença controlada. É essa licença que eu uso, é a licença controlada pelo pensamento. Então mesmo quando eu faço um trocadilho, ela [a licença] é controlada pelo pensamento.

Leonardo Bérenger: Suffocating Mothers, de Janet Adelman, é fundamental.

Lawrence Flores: É. E ela escreveu um outro texto fantástico que ela dedicou só ao poor Tom, ao pobre Tom do Lear.

Davi Pinho: Vamos então para a pergunta da Fernanda, também do setor de Literatura Inglesa da UERJ: “As tragédias são tradicionalmente mais valorizadas que as comédias - não necessariamente pelo público, mas pela academia, pela crítica e pelo mercado editorial. Consequentemente, temos mais traduções de tragédias do que dos demais gêneros shakespearianos (não só comédias, mas peças históricas e romances). Em última análise, isso contribui para circunscrever a ideia de 'Shakespeare' a um número restrito de obras, deixando muita coisa de fora da 'marca' Shakespeare. Gostaria de que você comentasse essa questão, e gostaria de saber quais não-tragédias você gostaria de traduzir, ou já traduziu".

Lawrence Flores: Pensei várias vezes em começar pelas comédias, mas não comecei pelas razões que eu já um pouco expus. Eu queria traduzir uma obra que todo mundo já tivesse traduzido para ver, realmente, a diferença com os procedimentos. E também para me colocar sobre os ombros deles, desses tradutores anteriores, não só brasileiros, franceses também. Por outro lado, acredito que o mais rico da obra de Shakespeare está na sua tragédia - e em particular, em Rei Lear. 
Davi Pinho: Este seu comentário é muito interessante porque pode revelar algum movimento "modernista" no seu impulso de tradução, Lawrence. Digo isso porque, se por um lado, como tradutor, você retoma aquelas traduções da década de 40 e 50, em dodecassílabos, você também retoma, com este foco nas quatro grandes tragédias, os primórdios de uma crítica shakespeariana mais acadêmica com A. C. Bradley. Há, então, um movimento de retorno e mudança que, de fato, poderia ser lido como modernista.

Lawrence Flores: Acredito que há um aporte modernista em minha tradução de Shakespeare e, com relação à crítica, retorno de fato à ideia de uma crítica que acredita na análise específica da obra, de suas relações internas, para interpretar, em lugar de submeter a obra a um projeto teórico específico ainda que também seria incorreto dizer que os "projetos críticos" (teóricos e outros), não apareçam na introdução que escrevi com Kathrin Rosenfield. Em Rei Lear, certa autonomia em relação ao estudo de contexto foi muito importante: em primeiro lugar, porque os estudos de contextos não produziram interpretações convincentes para a peça, tenderam muitas vezes a leitura anacrônicas ou ao apontamento simples de topicalidades. A peça é dramaticamente eficiente, no sentido de que seu poder estético, gigantesco, parece independente dos possíveis contextos aos quais ela se refere. É uma peça baseada em uma lenda, portanto Shakespeare sentiu-se mais livre ao escrevê-la do que ao escrever sobre reis medievais, sobre os quais podia acessar minuciosas informações e relatos na historiografia do período. A peça por assim dizer paira sozinha como um milagre estético, um sutil sistema de vasos comunicantes simbólicos, e foi a partir de sua análise específica que produzimos uma introdução calcada em sua autonomia artística, sem a exclusão de insights psicanalíticos e críticos de outros estudiosos.

Davi Pinho: E a próxima é Macbeth?

Lawrence Flores: A próxima é Macbeth. Para completar as grandes tragédias. Depois dela virá Sonho de uma noite de verão, Ricardo III e Ricardo II, não obrigatoriamente nesta ordem. 
Leonardo Bérenger: E depois?

Lawrence Flores: Não sei ainda, é possível que parta para a tradução de Milton. Mas não vamos prever o futuro.

Leonardo Bérenger: Ricardo II vai ser um grande desafio, pois vamos nos lembrar que é a única peça de Shakespeare $100 \%$ em versos.

Lawrence Flores: E vocês vão ver que meu verso vai recuar para um verso mais estável. Porque a versificação de Ricardo II é mais estável, por assim dizer, "perfeita", se comparada à das chamadas grandes tragédias - menos "prosaicas". O verso que eu estou usando agora é o verso mais apropriado para Hamlet, menos para Otelo. E sobretudo, o que eu entendo de mais apropriado para Lear, que é o caos, que é uma peça metricamente caótica e por gosto certamente, para refletir o caos no grande tema.

Leonardo Bérenger: Lawrence, você falou dessa imensidão do Lear. E a professora Marlene Soares dos Santos comenta que "A tragédia do Rei Lear é a única que apresenta um enredo secundário", é o famoso subplot. "Este enfoca a história do Conde de Gloucester e seus dois filhos. A cena mais impactante da peça e talvez de toda a dramaturgia shakespeariana é aquela em que vemos Gloucester ser violentamente cegado pelo Duque de Cornwall e descobrir sua injustiça para com o seu filho Edgar (3.7). Este é a figura mais importante da tragédia depois de Lear, dividindo com Kent o segundo lugar em números de linhas de falas, sendo que na versão do Folio a última fala é atribuída a ele." Agora, a pergunta da professora: "Você acha que a crítica, em geral, tem dado a devida importância ao subenredo da tragédia e à presença de Edgar, em particular?"

Lawrence Flores: A pergunta da Marlene, precisa como sempre, reflete de fato, não diria um vazio total na crítica, mas uma predominância que é surpreendente. O título da peça no in-quarto lembra que a peça é a tragédia de Rei Lear e de Edgar, o que reflete a intenção da peça e do próprio autor. 
Rei Lear como conhecemos é uma história, uma tragédia, que se afasta das fontes principalmente porque cria dois enredos que, no entanto, de algum modo se espelham e se nutrem mutuamente, quer pela própria polarização em um conflito entre pais e filhos, quer porque, malgrado o "espelhamento", elas mostram desfechos diferentes. Retomar o "milagre" estético resultante dessa combinação, dessa poesia "especular", dos estratos imaginários que reverberam seus conteúdos, seus vasos comunicantes sutis, é uma tarefa dificílima, porque o caminho interpretativo depende de microssugestões interiores no texto, mas também de várias outras coisas. Muitas vezes nos faltam categorias de análise para analisar Rei Lear. A posição de Edgar, para falar apenas de um modo rápido, é fundamental na peça: ela reverbera em parte a posição "fiel" de Cordelia, mas com muito mais sugestões. Tomemos, por exemplo, essa cena grandiosa, sugestiva, profundamente humana, que vemos junto aos penhascos de Dover, em que um filho salva o seu pai cegado por meio de um artifício teatral; pensemos, por outro lado, o quanto Edgar, ao retornar, é o protótipo do cavalheiro vingador, mas ao mesmo tempo se revela implacável em sua aparição. Pensemos na loucura de Poor Tom, e em como Shakespeare retoma os escritos de Samuel Harsnett para nos apresentar, ao final, como a teatralização pode ter funções curativas, numa espécie de sátira à sátira, por assim dizer. Com tudo isso vemos uma proeza tão rica de detalhes, tão intrincada, que quase soçobramos ao tentar explicála. Rei Lear sempre nos lançou uma pergunta sobre o estético, sempre colocou os críticos numa posição de contemplação, sem saber trazer ao certo as razões desse assombramento.

Davi Pinho: Vão se formando duplos o tempo todo em Lear. Eles vão se fazendo e reverberando por outros personagens. Com Lear e Edgar, esse paralelismo é muito frutífero.

Leonardo Bérenger: Sim, eles vão intensificando os sentimentos ali postos no palco, o que faz, talvez, com que Lear seja a mais trágica das tragédias.

Lawrence Flores: A gente tem dificuldade, inclusive, de explicar que técnica é essa que ele usou. Eu sempre termino com a palavra "ela é mágica", porque 
quando nós começamos a fazer a análise disso, acabamos perdendo o contato com o todo (que é o estético, a recepção), porque ela produz esse efeito através do estético, e não através, simplesmente, da acumulação do conhecimento sobre essa coisa. Realmente, no sentido assim de um conjunto simbólico da peça que passa a produzir efeitos, e, por outro lado, quando lemos um caso ou outro, o de Lear e o de Gloucester, somos obrigados a distinguir. Há uma leitura com caráter comparativo, justa sem dúvida, e uma outra que produzimos ao nível sensório mais elevado, estético, que nos revela e traz esse maravilhamento do sublime. Só lembrar uma coisinha para mostrar a validade dessa pergunta, no primeiro quarto a peça se chama "a verdadeira crônica histórica da vida e morte de Rei Lear e das suas três filhas, com a vida desafortunada de Edgar, filho e herdeiro do Earl of Gloucester e seu humor, como Tom of Bedlam". Então no primeiro quarto está escrito, quem quer que tenha escrito esse título, a gente não sabe quem, entendia que a peça tinha duas histórias, e tem duas histórias e elas se espelham. Nós temos em torno de Gloucester uma narrativa quase salvífica, no sentido quase teológico mesmo. Porque ele se salva, ele realmente é redimido pelo próprio filho que ele pôs à caça, enquanto no caso do Lear não há essa redenção claramente, há uma coisa muito mais ambígua, há o encontro do pai com a filha, mas nesse encontro ele continua sendo o Lear fusional, o Lear que quer se preencher com sua filha. Ele morre com sua falta, mas seria incorreto dizer que morre totalmente no erro - pois o reconhecimento do seu sofrimento existe. Mas ele não morre smilingly, como sorridente, como na morte afortunada do Gloucester.

Então Shakespeare colocou duas coisas que podiam trabalhar com a expectativa do público. E lembrando também que a antiga peça do King Leir, com $L-E-I-R$, da década de 90, que Shakespeare certamente conheceu, ela tinha um final feliz com o pai reencontrando-se com a filha, mas também restaurado, uma história de restauração do poder paterno. Não é isso que acontece no Rei Lear. A junção desses dois plots é absolutamente genial, é um dos grandes feitos artísticos da história. E sim, eu acho que a crítica não tem dado a devida importância, mas tem um texto, de novo da Janet Adelman, só sobre Poor Tom, que ela escreveu antes de seu grande livro Suffocating 
Mothers, que trata curiosamente da centralidade do Edgar como consciência, como coro da peça, como uma figura que dirige o movimento da peça, mais ou menos. Está em uma seleta de textos críticos chamada Twentieth Century Interpretations of King Lear: A Collection of Critical Essays (Englewood Cliffs, NJ: Prentice Hall, 1978, 134 pp). Porque tudo está em caos em volta, mas poor Tom, pobre Tom, é capaz de fazer um certo movimento. É uma figura apaixonante.

Leonardo Bérenger: Você falou na questão da peça de 1590. Depois, na Restauração, em 1681, Nahum Tate vai também fazer da peça um happy ending, happy ending este que vai permanecer nos palcos até Macready reestabelecer o texto dito original.

Davi Pinho: Eu acho que a gente pode terminar com uma pergunta especificamente sobre sua tradução de Lear. Você comenta nas suas notas sobre a dificuldade de traduzir o "poor Tom" e as tendências do passado ao traduzi-lo como um tipo "estereotipado". Quais foram os "antídotos" que você encontrou para essas traduções "estereotipadas"?

Lawrence Flores: $\mathrm{O}$ meu método para isso foi manter a grandeza dele e também a comicidade, um certo risível que ele tem, em função de ele ser uma figura que aparece como inferior, louca. Mas ele é comovente ao mesmo tempo. Então, uma das referências que me ocorreram no caminho foi o Riobaldo do Guimarães Rosa, uma personagem que Guimarães cria, retirado do sertão, rude na sua fala, um homem humilde, mas não caricaturado por um olhar positivista, um personagem cujo percurso autorreflexivo é comovente. Algo da tonalidade que Rosa deu ao seu Riobaldo - mas insisto, apenas "algo" - foi usado em minha tradução de algumas falas do Pobre Tom. É um modo muito sutil de mexer com a palavra, não localizá-la dentro de um lugar de preconceito, de preconceito inclusive linguístico. Mas, ao mesmo tempo, não renunciar, inteiramente, a esse estranhamento/familiaridade que eu tenho com essa outra linguagem agrária - e que traz a nossa própria condescendência e nostalgia urbana com algo que perdemos definitivamente. Entender que ela tem um pertencimento 
dela, mas que também eu homem culto também vejo isso, como os próprios personagens veem, como uma limitação.

Então, o que eu busquei, eu sempre penso assim "como é que vai ser o efeito disso?". O que eu busquei era criar algo familiar, mas que as pessoas não pudessem localizar diretamente em lugar nenhum em suas referências. É algo que faço na linguagem que os transporta a uma região linguística imaginária que eles já conhecem - mas evitando o pastiche, evitando a cópia exata... deixando a fala familiar levitar.

Davi Pinho: Lawrence, nós agradecemos muito a você, às colegas que contribuíram com perguntas, e à Marcela por ceder este espaço do Instagram para a nossa conversa!

Lawrence Flores: Deixa eu agradecer também à Cida, à Marlene, à Fernanda, à Alice, à Marcia. Maravilhosas perguntas, muito precisas.

Davi Pinho: Para nós, do Literatura Inglesa Brasil, é uma alegria fazer circular essa força que a universidade pública tem e que você faz despontar com tanta alegria, com tanta generosidade, com tanto afeto, mas com tanta seriedade de reflexão também! Obrigado! 